\title{
How does Colombia attract foreign direct investment?
}

\author{
Juan Carlos Botello \\ Martín Dávila \\ Carolyn Vargas
}

Universidad Popular Autónoma del Estado de Puebla, Mexico

\section{Keywords}

Theory, foreign direct investment, determinants, public policy, Colombia.

\begin{abstract}
During the eighties, Latin America was surrounded by economic crises, increased external debt, and poor growth of the Gross Domestic Product as well as little attraction of foreign direct investment (FDI).

Later in the nineties, some countries in the region inspired by the desire to eliminate the protectionist model had to undertake reforms that sought to achieve their commercial opening to start a new economic model and thereby show the world as an attractive area for attracting investment mainly from Europe and Asia.

One of the countries that made institutional changes by creating good conditions in the nineties as well as in the next decade to attract FDI was Colombia. The purpose of this paper is to demonstrate how Colombia attracted foreign capitals during 2005-2012. A probit model was applied (Botello, J.EDavila, M.,2015) to determine if the probability of improving the number of determinants to attract FDI will result in more inflows. The results show that the design of an industrial policy focused on attracting FDI, as well as the increase of the Gross Domestic Product, the offer of natural resources to foreign investors, the skilled workforce and the improvements in infrastructure were the determinants that increased the attraction of capitals. The implications for policy makers are to improve the rest of the determinants studied in this original research to increase the FDI flows into Colombia.
\end{abstract}

Corresponding author: Juan Carlos Botello

Email address for corresponding author: juancarlos.botello@upaep.mx

First submission received: $5^{\text {th }}$ June 2018

Revised submission received: $5^{\text {th }}$ November 2018

Accepted: $24^{\text {th }}$ November 2018

\section{Introduction}

In recent years, FDI has grown faster than trade flows and global production for various reasons such as political and economic changes in many developing countries. Those changes are characterized by the shift to democratic political systems as well as changes toward economic and legal systems oriented in the direction of trade liberalization in which Colombia and other countries played an important role since 1951 when signed as a GATT member.

Many developing countries have made economic and structural changes in order to obtain some benefits and attract FDI, in that sense, FDI flows are likely to be attracted to developing economies that pursue an outward-oriented strategy of economic development such as Colombia (IMF, 2015). In Latin America, the relative stability of the region and the adoption of outward-oriented public policies have reassured foreign and local investors based on market reforms. Because of such liberalization and changes, the FDI increased in developing countries in the 1990's (Erdal, F. \& Tatoglu, F., 2002) and particularly, Latin America has shown a sustainable growth since 2010 (ECLAC, 2013). 
On the other hand, the attractiveness of a state or a city for foreign direct investment flows depends on the number and kind of determinants they possess. Deichmann, J., Karidis, S. \&Sayek, S. (2003) found that some factors determining the spatial decisions of multinational firms in a Middle East country depend on policy implications. Considering the above, the government agenda should focus on making the country more attractive for FDI, especially in times of crisis when traditional determinants are put to the test and inspire proposals for new opportunities. Popovici, C. \& Calin, A. (2012) note that the idea of entering a new era of determinants of FDI is not new as there are several studies that highlight the key factors for attracting FDI. This emphasizes that the classical theories of FDI probably should be changed and others should be based on the emergence of new local capacities.

This research is divided as follows. In second part, a literature review is offered. Several research papers were analyzed to describe the key factors for attracting FDI considering classical theories in order to compare them with the determinants used by Mexico (Botello et al., 2015).Section three includes the data and variables used to explain the new determinant creation theory; based on the model proposed by Botello, et al. (2015) where the most relevant determinants used to obtain FDI are infrastructure, skilled labor, low labor cost, security, tax-break, natural resources, gross domestic product, legal system, geographical location and industrial policy. A probit model to test the theory in section four is presented. Finally, conclusions are discussed in section five.

\section{Literature review}

Latin America has undergone great economic changes. In 1982, the external debt crisis that affected the entire region exploded. Moreno, N. (2008) reported that this, generated capital flight and negative growth, which made that decade was considered "lost."At the same time, the economic policy of President Deng Xiao Ping helped make Latin America look very attractive to capitals from Asia, which allowed the arrival of volumes of investment, production and trade as well as the opening of multinational companies (Moreno, N., 2008). These were the beginnings of the flows of foreign investment in the region that originated the economic change that contributed to the stabilization of the crisis. After these events, positive changes began in the region; several contributions of Foreign Direct Investment (FDI) were made in the years 2005 to 2012. This contributed to a good and constant economic growth, since better investment flows were achieved like never before.FDI, in addition to be an opportunity for economic growth for each country, also means that it is one of the best and most effective ways to internationalize the region and make it a participant in globalization (Zapata, Y.; Kalmanovitz, S., 2007).

Latin America, in general, has seen economic stability from 2005 to 2012 (which is the period studied in this article), with steady annual growth that indicates that each year the government strategies work best for attract new companies to these territories (ECLAC, 2005) but in recent years FDI in the region continued trending downwards. In 2017, FDI flows into the region stood at US\$ 161.911 billion, $3.6 \%$ down on 2016. The main two reasons for the decline have been lower export commodity prices which have led to a substantial drop in investments in the extractive industries - and the economic recession in 2015 and 2016, mainly in Brazil, albeit also in other South American economies. These two trends, however, were partially reversed in 2017, as commodity prices recovered and the region returned to growth (1.3\%). Most of the literature related to the attraction of FDI by countries is based on different theories such as localization economies and their determinants, trade and resource endowments. In that sense, the eclectic paradigm of Dunning (1988) argues that the path FDI takes is partly due to the specific advantages which one country has, because of its regional geographic location and / or location in the world. These advantages arise from using resource endowments and / or assets held abroad by some countries in the world which are attractive to a company by combining them with its own resources. 
That combination suggests that if a foreign company wants to use the resources of a country, it should establish a subsidiary by initiating a flow of FDI and then establish a start-up operating facility (Hill, Ch., 2008) but, the risk is a main determinant that has to be considered. As of 2010, countries that wanted to invest in Latin America began to take an interest in the technology sector, but due to the low level of the industry, they took advantage of the opportunity to invest in low and medium-low technology (ECLAC, 2010). One of the sectors in which Latin America has been a recipient of investment from Europe is electricity, focused on the telecommunications, banking and energy subsectors (Zapata, Y., 2007).

On the other hand, one of the main reasons why the European Union decided to invest in Latin America is the opportunity that this region offers to access new and distant markets. Within the contribution of the Colombian legal framework as an incentive to attract FDI, there is a whole process to remove the protectionist model that historically had, this process began in 1990. It wanted to propose an opening of international competition, beginning by adapting neoliberal tendencies, efficient allocation of resources and institutional changes begun in the government of former President Virgilio Barco and at the beginning of the mandate of César Gaviria, with whom they became official and put into practice. These new policies were based on principles such as economic freedom, foreign trade reforms, labor legislation, foreign exchange regime, foreign investment policies, among others (Ramirez, C., 2011).

During the 2000s, the prohibition of FDI was eliminated in sectors that were previously not allowed and new financial, tax, labor, and port provisions were implemented in a positive manner, as well as an international investment statute. The law that stands out most is Law 963, made in 2005, under which investors will continue to be entitled to facilities and accessibility for them, under certain specifications imposed by the government (Ramirez, C., 2011). The elimination of infrastructure gaps plays a key role in sustaining strong and broad-based growth and supporting further economic diversification. Relatively weak road infrastructure represents an important obstacle not only for overall GDP growth, including through export diversification, but also for achieving a more evenly-distributed economic performance across regions in Colombia. In 2015, we see a recent progress in setting the proper conditions to foster private sector participation in infrastructure investment, so as to ensure efficient allocation of risks and macro financial stability (IMF, 2015).

The incentives that Colombia began to give to be a recipient of FDI are exemptions from the National Tax and Customs Directorate and the Bank of the Republic, especially located in places that promote trade, such as border areas and main ports (Barajas, 2011).According to Ramos, J. \&Rodríguez, K. (2011), the types of exemptions made by the government for Colombia to receive FDI are discounts on income, deduction, discounts on investment, and discounts on fixed assets. Something that was criticized a lot was that these benefits are given to companies that have the possibility of paying as a mark of the Law, and it is presumed that thanks to the fact that they enjoy these privileges, there has been an internal economic imbalance for the Colombian government, so you have to minimize public spending. Colombia has presented a constant evolution year after year. During the period from 2005 to 2009, FDI flows increased (ECLAC, 2009), although the years when FDI remains more stable are in 2005 and 2006, where there was also a large amount of commercial exchange (Kalmanovitz, S., 2007).

Likewise, the theory of international production suggests that the decision of a company to start manufacturing operations in other countries depend on certain attractions that the country of origin of the company has compared to the resources and benefits that it will obtain in locating a manufacturing subsidiary abroad (Morgan, R. \& Katsikeas, A., 1997). ECLAC (2010) reports that Colombia attracts the investment of several countries such as the United States, Canada and the United Kingdom, because they seek to expand new markets for their products as well as natural resources such as hydrocarbons, mining and agriculture.The natural resources of Colombia represent a great attraction for the countries, but above 
all for the United States, which is one of those that exploits them most and the "Plan Colombia" was a diplomatic-military strategy on the part of the United States for the role that play natural resources for this country (Delgado-Ramos, G. \&Romano, S., 2011). What the US did not imagine when implementing this geographical strategy, is that not only was it going to be an attraction for them, but also for other countries that are interested in Colombia, because they improve security and update the Colombian State forces.

As an important factor not only must be considered what investors intend, but also what Colombia offers as competitive advantages so that these investors are interested in Colombia. According to the publications of Montoya, C. (2011), Colombia offers a better allocation of resources, exploitation of economies of scale as well as greater efficiency which led to an increase in GDP per capita during 2009. Most of investments made in Latin America have a significant impact on the consolidation or diversification of the production profiles, particularly as foreign direct investment has a major impact on host economies, roughly measure the relationship between foreign direct investment and gross domestic product (ECLAC, 2011). Hausmann, R. \& Klinger, B. (2008), explained that there are some key determinants related to the increase in foreign direct investment worldwide as well as the Andean countries, among these determinants are the location, the size of the country in terms of GDP and the distance between the investors and the host countries.

The theory of trade and resource endowment explains that FDI is directed toward countries with low wages and abundant natural resources that provide inherent differences of opportunity and initial favorable conditions for businesses. There is a consensus about the characteristics required for a host country to attract FDI which is that it depends on the motivations that foreign investors have in relation to their investment projects. According to Dunning (1983), the first reason is related to the market, whose main purpose is to serve local and regional markets from the FDI host country if the market grows and generate some return for the investor, the second relates to the investment made by a company in acquiring resources that are not available in the country of origin such as natural resources and low-cost inputs including labor. The latter corresponds to the level of efficiency achieved through the dispersion of value chain activities considering that the geographical proximity to the country of origin will minimize transportation costs.

All this suggests that the direction, in which FDI is aimed, is highly related to the comparative advantages (Kinoshita, Y., 2003) of a given country. Then, one country that has, among other determinants, access to markets as well as cheap labor and abundant natural resources will attract larger inflows of FDI. Berkoz, L. \& Sence, S. (2009) argues that countries have traditional factors and environmental variables that are attractive to foreign companies. The traditional factors are market potential, labor costs, economic growth and government policies. The environmental variables correspond to political, economic, legal and infrastructural factors.

In terms of geographical location, one of the greatest attractions for FDI flows in Latin America is that easy access to exit from two Oceans, although there are several countries that have only one outlet (ECLAC, 2009). Kinoshita, Y. (2003) in turn, maintains that the most important determinants a country has to attract FDI are government institutions, natural resources and economies of agglomeration. Government institutions are one factor contributing to decisions by investors as to whether to invest or not in a particular country because these institutions directly affect the operating conditions of enterprises. The investment cost for companies is not only economic but they also have to fight against entrenched practices in countries such as bribery and time lost in engaging in diverse and various negotiations resulting from the arrival of the company to a new market. Therefore, for the operating conditions of a company to appear reliable to the investor, there are two institutional variables to be considered: The legal 
system and the quality of the bureaucracy. As for the legal system, both its impartiality as well as popular perception of it is good determinants of the reliability of legal institutions in the country.

Likewise, the variable related to the quality of the bureaucracy describes a non-political and professional bureaucracy which in turn facilitates the procedures for staff to be hired. With respect to agglomeration economies, investors seek those markets where there are benefits derived from the concentration of economic units which results in positive externalities (benefits and technological spill, use of skilled labor and concentrated in specific locations and links forward and backward with related industries) but also by investments made by other investors which can be seen as a positive sign of favorable investment conditions reducing uncertainty. As for the natural resources, Rasiah (2000) argues that developing economies with a resource-rich endowment obtains FDI.

Other studies describing the FDI determinants indicate that the infrastructure, good governance, taxes (Rasiah, 2000) and the labor market are conditions that governments must maintain (Bellak, C., Leibrecht, M. \& Liebensteiner, M., 2010) but Lim, D. (1983) found a negative relationship between investment incentives and FDI in 27 developing countries. Groh, A. and Wich, M. (2009) describe the determinants to attract FDI in a country as labor costs, quality and the provision of quality infrastructure and legal systems. On the other hand, some authors consider that the provision of infrastructure should be a precondition for companies to establish subsidiaries in foreign markets as are a major emphasis on the provision of transport infrastructure as well as information and communication technologies (Botric, V.\& Skuflic, L., 2006; Goodspeed, T., Martinez-Vazquez, J.\& Zhang, L., 2009).

Studies by Wei, Y., Liu, X., Parker, D. \& Vaidya, K. (1999), Mariotti, S. \& Piscitello, L. (1995), and He, C. (2002) conclude that there is a positive relationship between infrastructure and FDI because the better the infrastructure is in a location the higher its desirability. Rasiah (2000), states out that FDI in developing countries is concentrated in economies endowed with good infrastructure. In a research conducted by Botello, J \& Davila, M. (2013), concluded that public policy used in some states of Mexico to attract FDI, is based on the attractiveness of some determinants like skilled labor, cheap labor and infrastructure.

Another factor that helped to generate the increase of FDI in Colombia was the infrastructure. The total infrastructure investment in Colombia has been volatile averaging 4.6 percent of GDP in 1995-2004 and only over the last decade it steadily increased to above 7 percent of GDP in recent years (ECLAC 2015).

Various studies indicate that infrastructure quality in Colombia is relatively low and logistic costs are high both at regional and global level. In the World Bank's 2014 Logistics Performance Index, Colombia ranks 97th among 160 countries, one of the worst performers relative to regional peers, with the poorest outcomes in infrastructure, timeliness, and tracking and tracing. The country ranks 93th among 189 economies in the World Bank's 2015 Doing Business indicator related to ease of cross-border trade, which predominantly highlights the country's high inland transportation costs and time in performing a foreign trade transaction. In particular, exporting/importing costs in Colombia are mainly associated with inland transport, and these costs are more than double the LAC and OECD averages. Furthermore, World Economic Forum (WEF 2014-15) ranked Colombia 126 among 144 countries in terms of road infrastructure quality, the lowest ranking in the country's overall infrastructure quality (ranked 84) and the worst performance among regional peers. The gaps in port and airport infrastructure are less significant, although most of them are already operating at full capacity, and this will only worsen with increased trade and passenger demand (ECLAC, 2015).

The lack of roads and deficient road conditions are obstacles to rural areas' connection to the rest of the country. Isolation hinders access to public services, precludes selling of products to larger markets, limits economic opportunities, and restrains regional integration and competitiveness. While upgrading national road network through concessions are important to connecting rural areas with markets, 
improving the connectivity and quality of secondary and tertiary roads is crucial for both regional development and reducing rural poverty (ECLAC, 2015).Significant changes for infrastructure development in Colombia were introduced with the adoption of Law 1508 of 2012 on Public Private Partnerships (ECLAC, 2015).FDI inflows into Colombia reached US\$ 13.924 billion in 2017, up 0.5\% on 2016 levels and close to those recorded between 2011 and 2014. Reinvested earnings increased significantly for the year, especially in the fourth quarter, reflecting the increase in the price of oil, as well as the overall improvement of the economy in the second half of the year (ECLAC, 2018).

The transport and telecommunications sector were the main FDI recipient in 2017 (US\$ 3.136 billion), matching investment flows to the oil sector (US\$ 3.135 billion), traditionally the largest recipient of FDI in Colombia. Between 2011 and 2014, the oil sector over received US\$ 5 billion annually, but these inflows halved in 2015 and 2016. The rise recorded in 2017, and in the first months of 2018, reflects the pick-up in investment resulting from the increase in prices. The mining sector also benefited from this situation, with investments in 2017 rising to US\$ 953 million. FDI in the manufacturing sector also increased, almost reaching its highest level in the past 10 years, at US\$ 2.523 billion (ECLAC, 2018). On the other hand, as opposed to what Botello et al. (2013) concluded, Ondrich, J.\& Wasylenko, M. (1993) and Rasiah, R. (2000) found that there is no evidence that wages affect the location of new foreign plants, especially cheap labor but that it's not the case for skilled labor. Flexible production forms have given rise to greater dispersal of organizational power as well as process innovation; local accumulation at peripheral sites has stimulated economic progress, albeit only in locations generating the requisite skills (Rasiah, R., 2000), suggesting that specialized FDI requires skilled labor.

According to the research studies mentioned above, there are similarities in the description of the traditional determinants, which explain the attractiveness of a country with respect to foreign capital which suggests that the design of public policy in some countries like Colombia, in relation to attracting financial resources from abroad, is very similar. Berkozet al. (2009) found almost the same determinants for the case of Turkey and suggests that a location analysis needs to be done in order to develop specific growth strategies to be applied by policy-makers in their plans to attract FDI to certain locations. Figueroa (2012) assumes that tax facilities, proximity to markets, and cheap labor are insufficient factors to guarantee the cycle of capital, since what stands out is the outgoing transfer of the innovation activity itself, which suggests that the attraction of new FDI flows requires the creation of new determinants or the renewal of the most used. The advance of global knowledge has become itself as an attractive determinant to catch the attention of investors. In recent years, many countries around the world are worried about the way they are going to attract capitals. Perhaps, their research agenda would change to more focused analyses of the fundamental determinants that drive such flows of FDI. Should they create new determinants or renewal the ones that are already used to?

\section{Objectives, variables, hypotheses and data \\ Objectives}

The objective of this research is to find out the determinants used by Colombia during 2005 through 2012 to attract foreign direct investment applying the new determinant creation theory proposed by Botelloet al. (2015)

\section{Variables}

The dependent variable used in this research is:

fdi (amount of foreign direct investment). Foreign Direct Investment (FDI) has been selected as a dependent variable relative to the amount of Colombia's foreign direct investment inflows from 2005 to 2012.impde (improvement of determinants). This variable was selected as a dependent variable to use it in 
the probit model in order to explain if the probability of improvement of the determinants used to attract foreign direct investment contributed to increase inflows from 2005 to 2012 by Colombia.

The independent variables in their different modalities that will be considered for the theoretical model are:

3.2.3ifra (infrastructure). This variable explains if infrastructure was used as a determinant to attract foreign direct investment from 2005 to 2012 by Colombia. Infrastructure is considered as paved roads $(\mathrm{km})$ and airports (number).

3.2.4 qualab (qualified labor). This variable explains if skilled labor was used as a determinant to attract foreign direct investment from 2005 to 2012 by Colombia. This variable was measured by the number of professionals that Colombia has.

3.2.5wage (minimum wage). This variable explains if low cost labor was used as a determinant to attract foreign direct investment from 2005 to 2012 by Colombia.

3.2.6sec (security). This variable explains if security was used as a determinant to attract foreign direct investment from 2005 to 2012 by Colombia.

3.2.7taxex (exemption from tax payment). This variable explains if exemption from tax payment was used as a determinant to attract foreign direct investment from 2005 to 2012 by Colombia.

3.2.8natures (natural resources). This variable explains if natural resources were used as a determinant to attract foreign direct investment from 2005 to 2012 by Colombia.

3.2.9gnp (gross national product). This variable explains if gross national product was used as a determinant to attract foreign direct investment from 2005 to 2012 by Colombia.

3.2.10legal (legal framework). This variable explains if a legal framework was used as a determinant to attract foreign direct investment from 2005 to 2012 by Colombia.

3.2.11geoloc (geographical location). This variable explains if geographical location was used as a determinant to attract foreign direct investment from 2005 to 2012 by Colombia.

3.2.12indpol (industrial policy). This variable explains if a foreign direct investment industrial policy was used as a determinant to attract foreign direct investment from 2005 to 2012 by Colombia.

\section{Hypotheses}

For main model is:

$\mathrm{H}_{1}$ : The attraction of foreign direct investment in Colombia depend on infrastructure development, on skilled labor, on low cost labor, on security, on tax exemption, on natural resources, on gross national product, on legal framework, on geographical location and industrial policy from 2005 to 2012 . Once the main model has been demonstrated, it is important that the model is then tested by discarding the variables whose significance is lower and testing the model with the variables that are more efficient (Wooldridge, J., 2015 \& Heij, Ch., De Boer, P., Franses, P., Kloek, T. \&Van Dijk, H., 2004). For this case, the most efficient variables for the Probit model are:

$\mathrm{H}_{2}$ : The probability of improving infrastructure, skilled labor, low cost labor, security, tax exemption, natural resources, gross national product, legal framework, geographical location and industrial policy will attract more foreign direct investment flows.

\section{Data}

Reports from Colombia's government from 2005 through 2012 were reviewed by the authors to build a database in this research. By using the methodology to test the new determinant creation theory proposed by Botello et al. (2015) to the case of Colombia, the authors found that the design of an industrial policy focused on attracting FDI, as well as the increase of the Gross Domestic Product, the offer of natural 
resources to foreign investors, the skilled workforce and the improvements in infrastructure were the determinants that increased the probability of attracting capitals from abroad.

\section{Methodology, Models and Results}

\subsection{Methodology}

To test the hypotheses, we carried out several models of time series data, the results for these models indicate the nature of each of the variables used, and the relationship with the dependent variable. Once we have variables that will be employed in a probit model originally used by Bliss (1934) as well as applied to stochastic models by Steinbrecher, G.\& Shaw, T. (2008) it was necessary to check and simulate the dependent variable (impde), which was developed as the probability that there is an improvement in the determinants that each one of the Colombian departments used in their public policies and in their development plans, related to foreign direct investment flows. The probit model tested the hypotheses and the main objective of this research.

The probit model was used to measure the probability of Colombia's FDI attraction based on the new determinant creation theory. The database developed for this study contains data of the determinants used by Colombia for a period of eight years. During those years, there are departments that do not use the ten determinants commonly used to attract foreign direct investment according to the model proposed by Botello, et al. (2015) or there are departments that decide to improve the determinants they commonly use or use only the determinants that they possess.

\subsection{Models}

The following equations are the proposal models to prove the hypotheses postulated earlier:

Main model is:

$$
\begin{gathered}
\text { fdi }_{t}=\beta_{0}+\beta_{1} \text { ifra }_{t}+\beta_{2} \text { qualab }_{t}+\beta_{3} \text { wage }_{t}+\beta_{4} \text { sec }_{t}+\beta_{5} \text { taxex }_{t}+\beta_{6} \text { natures }_{t} \\
+\beta_{7} \text { gnp }_{t}+\beta_{8} \text { legal }_{t}+\beta_{9} \text { geoloc }_{t}+\beta_{10} \text { indpol }_{t}+u_{t}
\end{gathered}
$$

For the main model we have the following equation for efficiency:

$$
\begin{gathered}
\text { fdi }_{t}=\beta_{0}+\beta_{1} \text { ifra }_{t}+\beta_{2} \text { taxex }_{t}+\beta_{3} \text { natures }_{t}+\beta_{4} \text { gnp }_{t}+\beta_{5} \text { legal }_{t}+\beta_{6} \text { indpol }_{t} \\
+u_{t}
\end{gathered}
$$

This probit model is that represent the whole variables in this model:

$$
\begin{aligned}
P\left(\text { impde }_{t}\right)= & \beta_{0}+\beta_{1} \text { ifra }_{t}+\beta_{2} \text { qualab }_{t}+\beta_{3} \text { wage }_{t}+\beta_{4} \text { sec }_{t}+\beta_{5} \text { taxex }_{t} \\
& +\beta_{6} \text { natures }_{t}+\beta_{7} \text { gnp }_{t}+\beta_{8} \text { legal }_{t}+\beta_{9} \text { geoloc }_{t}+\beta_{10} \text { indpol }_{t}+u_{t}
\end{aligned}
$$

The next probit model is that represent the most efficient variables:

$$
P\left(\text { impde }_{t}\right)=\beta_{0}+\beta_{1} \text { ifra }_{t}+\beta_{2} \text { qualab }_{t}+\beta_{3} \text { natures }_{t}+\beta_{4} \text { gnp }_{t}+\beta_{5} \text { indpol }_{t}+u_{t}
$$

\subsection{Results}

As the models described before were handled through time series, we verified that the variables have a stationary stochastic process. The variables presented a nonstationary process so, the models are not useful to find reliable results by the method of ordinary least squares (OLS), in accordance with Engle, R.\& Granger, C. (1987) that conducted a cointegration study. Then, we made a linear combination of two series, each of which is integrated of any kind of order, additionally checked and corrected the errors through the Granger causality (Granger, C., 1969 \& Granger, C. \&Newbold, P., 1974) to verify that indeed 
the time series used are stationary, the following model show this test and in the Table A1 are the results for them:

$$
f d i_{t}=\delta_{0}+\alpha_{1} f d i_{t-1}+\alpha_{2} f d i_{t-2}+\alpha_{3} f d i_{t-3}+\alpha_{1} f d i_{t-4}+\gamma_{1} i f r a_{t-1}+\gamma_{2} i f r a_{t-2}+u_{t}
$$

In addition, was revised collinearity of the variables through a model of vector autoregressive (VAR), where it was found that indeed the variables presented a high collinearity and that has to be corrected for the stationary variables; besides that, we use the Wald test (Wald, A., 1940) to prove if the model has an asymptotic chi-square distribution. The model was as follows and in Table A2 we show the results for them:

$$
f d i_{t}=\delta_{0}+\alpha_{1} f d i_{t-1}+u_{t}
$$

Once we have corrected the errors that could be present in the time series, and we are sure that the variables shown a Stationary Stochastic Process we proceeded to find the corresponding relations with each of the proposed variables as determinants for foreign direct investment flows that have been submitted in Colombia by 2005 to 2012.

The interaction of all independent variables in the Main model is shown with respect to the dependent variable in Table A3. It was expected that all the variables were significant but, the independent variables ifra, qualab, natures, gnp and geoloc (corresponding to infrastructure, qualified labor, natural resources, gross national product and geographical location), were not.

Subsequently, the interaction of the dependent variable with each of the independent variables was done to confirm its significance, the models were shown before. The results (see Table A4) demonstrate that almost all the variables have a high significance more than $95 \%$, except natures. Once interactions were tested using linear regressions, a simulation using the probit model was done. The results showed that the probability of an improvement in the determinants increased flows of foreign direct investment. The presented results correspond to the model and we only use the most efficient variables to demonstrate the theory (see Tables A5 and A6).

\section{Conclusions}

The theories proposed by several authors to explain how countries attract FDI are diverse. Some of them are based on the use of different determinants as part of its public policy like the new determinant creation model proposed by Botello, et al. (2015). Considering that model, during the 2005-2012 period, Colombia also used ten determinants to attract foreign direct investment, however, the main model with efficiency demonstrated that the most important determinants used by Colombia to attract FDI were infrastructure, tax exemption, natural resources, gross national product, legal framework and industrial policy. Since the period studied is eight years, it was observed that some departments in Colombia during that period decided to create or renew their determinants in order to attract more and new flows of foreign direct investment. In that sense, the purpose of this article was to test the new determinant creation theory proposed by Botello et al. (2015) as part of the public policy of Colombia and the probit model demonstrates that relationship.

In Table A6, we see that Colombia is currently using infrastructure, qualified labor, natural resources, gross domestic product, and industrial policy, as the most relevant determinants of the tenth to attract inflows. A report from ECLAC (2015) indicates an important increase in FDI flows. Colombia is capturing more inflows related to its gross national product. As a last idea, if any government in the world is interested in attracting new or more foreign direct investment must create or renovate the determinants used to attract investment flows. There are probably cities or provinces who want to attract resources for certain types of industry, but they must create or renew the related determinants, such that the different 
types of industry prevailing in a country use different determinants and some of them they shall not be used to attract new resources and should focus on the development of new determinants.

\section{Discussion}

The implications of the theories of FDI for both, business practices and government policies are straightforward. The location-specific advantages argument associated with John Dunning does help explain the direction of FDI (Hill, Ch. \& Hult, G., 2017). However, the location-specific advantages argument does not consider the exploitation of natural resources and the implications on global climate change. According to the Global Investment Competitiveness survey 2017/2018 (World Bank, 2017), investors consider a broad range of factors in their decision to invest, including political stability and security, legal and regulatory environment, large domestic market size, macroeconomic stability and favorable exchange rate, available talent and skilled labor, good physical infrastructure, low taxes rate, low cost of labor and inputs, access to land and financing in the domestic market. The survey of investors shows that political stability and security, together with the presence of a stable legal and regulatory environment in the country, are the main characteristics that executives of multinational companies consider before committing capital in a new operation. These considerations have much more weight than issues such as tax rates or low labor costs. For policy makers, designing policies to attract FDI considering the negative impact on global climate change should be the agenda. In such cases, a firm considering FDI should comply with government's regulations in order to achieve its strategy.

\section{References}

Barajas, R. (2010). Beneficios tributarios y su relación con el déficit fiscal en Colombia, durante el período comprendido entre los años 2005 y 2010 (Tax benefits and their relation to the fiscal deficit in Colombia, during the period between 2005 and 2010). Investigaciones UNAD Bogotá, 02, 239-261.

Bellak, C., Leibrecht, M. \& Liebensteiner, M. (2010). Attracting Foreign Direct Investment: the public policy scope for south east European countries. Eastern Journal of European Studies, 1(2), pp. 37-53

Berkoz, L. \& Sence, S. (2009). Locational Preferences of FDI Firms in Turkey: A Detailed Examination of Regional Determinants. European Planning Studies, 17(8), pp. 1243-1256

Bliss, Ch. (1934). The method of probits. Science, 79 (2037), pp. 38-39.

Botello, J. \&Davila, M. (2013). Public Policy as a Determinant for Attracting Foreign Direct Investment in Mexico since 2000-2013.International Journal of Business and Economic Development, 2(1), pp. 78-89

Botello, J. \& Davila, M. (2015). The new determinant creation theory: a way to attract new foreign direct investment flows. International Journal of Business and Economic Development, 3(1), pp. 96-109

Botric, V.\&Skuflic, L. (2006). Main determinants of foreign direct investment in the southeast European countries. Transition Studies Review, 13(2), pp. 357-377

Deichmann, J., Karidis, S. \& Sayek, S. (2003). Foreign Direct Investment in Turkey: Regional Determinants, Applied Economics, 35(16), pp. 1767-1778.

Delgado-Ramos, G. \& Romano, S. (2011). Plan Colombia e Iniciativa Mérida: Negocio y Seguridad Interna (Plan Colombia and Mérida Initiative: Business and Internal Security). El Cotidiano, (170), pp. 89-100

Dunning, J. (1988). Explaining international production. London: Unwin Hyman

Economic Commission for Latin America and The Caribbean (2005). La Inversión Extranjera Directa en America Latina y el Caribe (Foreign Direct Investment in Latin America and the Caribbean). Unidad de Inversiones y Estrategias Empresariales. Santiago de Chile: CEPAL.

Economic Commission for Latin America and The Caribbean (2009). La Inversión Extranjera Directa en America Latina y el Caribe (Foreign Direct Investment in Latin America and the Caribbean). Unidad de Inversiones y Estrategias Empresariales. Santiago de Chile: CEPAL.

Economic Commission for Latin America and the Caribbean (2010). La Inversión Extranjera Directa en America Latina y el Caribe (Foreign Direct Investment in Latin America and the Caribbean). Unidad de Inversiones y Estrategias Empresariales. Santiago de Chile: CEPAL. 
Economic Commission for Latin America and The Caribbean (2011). La Inversión Extranjera Directa en America Latina y el Caribe (Foreign Direct Investment in Latin America and the Caribbean). Unidad de Inversiones $y$ Estrategias Empresariales. Santiago de Chile: CEPAL.

Economic Commission for Latin America and The Caribbean (2013). La Inversión Extranjera Directa en America Latina y el Caribe (Foreign Direct Investment in Latin America and the Caribbean). Unidad de Inversiones y Estrategias Empresariales. Santiago de Chile: CEPAL.

Economic Commission for Latin America and The Caribbean (2015). La Inversión Extranjera Directa en America Latina y el Caribe (Foreign Direct Investment in Latin America and the Caribbean). Unidad de Inversiones y Estrategias Empresariales. Santiago de Chile: CEPAL.

Economic Commission for Latin America and The Caribbean (2018). La Inversión Extranjera Directa en America Latina y el Caribe (Foreign Direct Investment in Latin America and the Caribbean). Unidad de Inversiones y Estrategias Empresariales. Santiago de Chile: CEPAL.

Engle, Robert F. \& Clive W. J. Granger (1987). Cointegration and Error Correction: Representation, Estimation, and Testing. Econometrica, 55(2), pp. 251-276

Erdal, F. \&Tatoglu, F. (2002). Locational Determinants of Foreign Direct Investments in an Emerging Market economy: The Turkish experience, Multinational Business Review, 10(1), pp. 21-27

Figueroa, S. (2012). Emergent Vulnerability in Attracting Foreign Direct Investment in Latin America: The Case of Mexico. Perspectives on Global Development and Technology, 11, pp. 374-385

Goodspeed, T., Martinez-Vazquez, J. \& Zhang, L. (2009). Public Policies and FDI Location: Differences between developing and developed countries, International Studies Program Working Paper, GDU paper No 0910

Granger, C. (1969). Investigating causal relations by econometric models and cross-spectral methods. Econometrica, 37(3), pp. 424-438

Granger, C. \& Newbold, P. (1974). Spurious Regressions in Econometrics. Journal of Econometrics, 2, pp. 111-120

Groh, A., \&Wich, M. (2009). A Composite Measure to Determine a Host Country's Attractiveness for FDI. IESE Business School Working Paper Number 833

Hausmann, R. \& Klinger, B. (2008). Grow Diagnostic: Peru. Center for International Development Harvard University.

He, C. (2002). Information costs, agglomeration economies and the location of foreign direct investment in China, Regional Studies, 36(9), pp. 1029-1036

Heij, Ch., De Boer, P., Franses, P., Kloek, T.\&Van Dijk, H. (2004), Econometric Methods with Applications in Business and Economics. United Kingdom: Oxford University Press.

Hill, Ch. (2012). International Business.12 Ed. USA: McGraw Hill.

Hill, Ch. \&Hult, G. (2017). International Business. 11 Ed. USA: McGraw Hill.

International Monetary Fund (2015). Colombia, IMF Country Report 15/143. Washington: IMF

Kalmanovitz, S. (2007). Colombia en las dos fases de Globalización (Colombia in the two phases of Globalization). Economía Institucional, 9, pp. 45-58.

Kinoshita, Y. (2003). Why does FDI go where it goes? New Evidence from the transition economies. William Davidson Institute Working Paper Number 573

Lim, D. (1983). Fiscal incentives and direct foreign investment in less developed countries, Journal of Development Studies, 19(2), pp. 207-212

Mariotti, S. \& Piscitello, L. (1995) Information Cost and Location of FDI's Within the Host Country: Empirical Evidence from Italy, Journal of International Business Studies, 26(4), pp. 815-840

Montoya, C. (2011). Colombia y su inserción a la economía mundial (Colombia and its insertion in the world economy). Ecos de Economía, 32, pp. 173-192.

Moreno, N. (2008). El patrón de los flujos de inversión extranjera directa en los países de América Latina (1991-2005) (The pattern of foreign direct investment flows in Latin American countries). Pensamiento y Gestión, 24, pp. 1-17

Morgan, R., \& Katsikeas, A. (1997). Theories of international trade, foreign direct investment and firm internationalization: a critique, Management Decision, 35(1), pp. 68-78

Ondrich, J. \&Wasylenko, M. (1993). Foreign Direct Investment in the United States (Kalamazoo, MI: W.E. Upjohn Institute for Employment Research) 
Popovici, C., \&Calin, A. (2012). Attractiveness of Public Policies for Fdi In Central and Eastern European Countries. Annals of Faculty of Economics, 1(1), 61-67.

Ramírez, C. (2011). Marco jurídico de la Inversión Extranjeraen Colombia (Legal framework of Foreign Investment in Colombia). Saber y Ciencia, 1, 163-175.

Ramos, J. \& Rodríguez, K. (2011). Zonas Francas en Colombia: beneficios tributarios en el impuesto de renta (Free Trade Zones in Colombia: tax benefits in the income tax). Borradores de economía. 657,pp. 1-19.

Rasiah, R. (2000). Globalization and Private Capital Movements. Third World Quarterly, 21(6), pp. $943-961$.

Steinbrecher, G. \& Shaw, T. (2008). Quantile mechanics. European Journal of Applied Mathematics 19(2), pp. 87-112.

Wald, A. (1940). The Fitting of Straight Lines if Both Variables are Subject to Error. Annals of Mathematical Statistics, 11, pp. 284-300.

Wei, Y., Liu, X. Parker, D. \& Vaidya, K. (1999). The Regional Distribution of Foreign Direct Investment in China. Regional Studies, 33(9), pp. 857-867.

Wooldridge, J. (2015), Introductory Econometrics: A Modern Approach. 6 Ed. USA: Cengage Learning.

World Bank. (2018). Global Investment Competitiveness Report 2017/2018: Foreign Investor Perspectives and Policy Implications. Washington, DC: World Bank.

Zapata, Y. (2007). La Inversion Extranjera Directa de la Unión Europeahacia América Latina: El método de entrada de las principals multinacionale seléctricas (The Direct Foreign Investment of the European Union towards Latin America: The entry method of the main electric multinationals). Estudios Gerenciales, 23, pp. 41-52.

Appendix

Table A1. Econometric results for the Vector Autorregresive (VAR) models, to prove collineality.

\begin{tabular}{|c|c|c|c|c|c|c|}
\hline & Coef. & Std. Err. & $z$ & $P>|z|$ & \multicolumn{2}{|c|}{ [95\% Conf. Interva1] } \\
\hline \multicolumn{7}{|c|}{ (2) } \\
\hline L1 & 0.9717 & 0.0711 & 13.67 & 0.000 & 0.8324 & 1.1110 \\
\hline L.2 & -0.0046 & 0.0711 & -0.06 & 0.949 & -0.1440 & 0.1348 \\
\hline \multicolumn{7}{|l|}{ ifra } \\
\hline L1 & 42.4443 & 81.9408 & 0.52 & 0.604 & -118.1567 & 203.0454 \\
\hline L2 & 70.9483 & 79.3382 & 0.89 & 0.371 & -84.5517 & 226.4482 \\
\hline \multicolumn{7}{|l|}{ qualab } \\
\hline L1 & -155.9970 & 123.3170 & -1.27 & 0.206 & -397.6939 & 85.6999 \\
\hline L2 & -106.9871 & 124.8019 & -0.86 & 0.391 & -351.5943 & 137.6200 \\
\hline \multicolumn{7}{|l|}{ wage } \\
\hline L1 & 35.8423 & 69.6527 & 0.51 & 0.607 & -100.6744 & 172.3591 \\
\hline L2 & 102.5203 & 68.8440 & 1.49 & 0.136 & -32.4114 & 237.4520 \\
\hline \multicolumn{7}{|l|}{$\sec$} \\
\hline L1 & 48.5407 & 80.2129 & 0.61 & 0.545 & -108.6737 & 205.7550 \\
\hline L.2 & 71.4972 & 79.6543 & 0.90 & 0.369 & -84.6223 & 227.6166 \\
\hline \multicolumn{7}{|l|}{ taxex } \\
\hline L1 & -4.5563 & 84.0637 & -0.05 & 0.957 & -169.3182 & 160.2055 \\
\hline L.2 & -67.1570 & 83.5940 & -0.80 & 0.422 & -230.9983 & 96.6843 \\
\hline \multicolumn{7}{|c|}{ natures } \\
\hline L1 & 11.9234 & 108.7278 & 0.11 & 0.913 & -201.1792 & 225.0260 \\
\hline $\mathrm{L} 2$ & 35.2119 & 108.1363 & 0.33 & 0.745 & -176.7312 & 247.1551 \\
\hline \multicolumn{7}{|l|}{$g n p$} \\
\hline L1 & -26.8855 & 60.5283 & -0.44 & 0.657 & -145.5187 & 91.7478 \\
\hline L2 & -64.5067 & 61.9706 & -1.04 & 0.298 & -185.9668 & 56.9534 \\
\hline \multicolumn{7}{|l|}{ legal } \\
\hline L1 & -0.0681 & 75.9335 & 0.00 & 0.999 & -148.8950 & 148.7588 \\
\hline L.2 & -86.5309 & 74.7012 & -1.16 & 0.247 & -232.9426 & 59.8807 \\
\hline \multicolumn{7}{|l|}{ geoloc } \\
\hline L1 & 38.6188 & 76.8745 & 0.50 & 0.615 & -112.0525 & 189.2900 \\
\hline L.2 & 122.1764 & 74.2823 & 1.64 & 0.100 & -23.4141 & 267.7669 \\
\hline \multicolumn{7}{|l|}{ indpo1 } \\
\hline L1 & 66.1555 & 76.5733 & 0.86 & 0.388 & -83.9254 & 216.2364 \\
\hline L.2 & -14.7984 & 78.4126 & -0.19 & 0.850 & -168.4842 & 138.8874 \\
\hline cons & 51.6429 & 205.5020 & 0.25 & 0.802 & -351.1337 & 454.4195 \\
\hline
\end{tabular}

Table A2. Econometric results for find the Granger causality Wald tests. 


\begin{tabular}{ccccc}
\hline Equation & Excluded & chi2 & df & Prob > chi2 \\
\hline fdi & ifra & 1.1730 & 2 & 0.556 \\
fdi & qualab & 2.3007 & 2 & 0.317 \\
fdi & wage & 2.4190 & 2 & 0.298 \\
fdi & sec & 1.1734 & 2 & 0.556 \\
fdi & taxex & 0.6455 & 2 & 0.724 \\
fdi & natures & 0.1095 & 2 & 0.947 \\
fdi & gnp & 1.4311 & 2 & 0.489 \\
fdi & legal & 1.3498 & 2 & 0.509 \\
fdi & geoloc & 2.7986 & 2 & 0.247 \\
fdi & indpol & 0.7571 & 2 & 0.685 \\
fdi & ALL & 13.4860 & 20 & 0.856 \\
\hline
\end{tabular}

Table A3. Econometric results to prove the Main model.

\begin{tabular}{ccccccc}
\hline fdi & Coef. & Std. Err. & $z$ & $P>|z|$ & \multicolumn{2}{c}{$[95 \%$ Conf. Interval] } \\
\hline ifra & -1624.74 & 623.42 & -2.61 & 0.009 & -2850.29 & -399.20 \\
qualab & -667.05 & 549.77 & -1.21 & 0.226 & -1747.82 & 413.72 \\
wage & 162.63 & 436.42 & 0.37 & 0.710 & -695.30 & 1020.55 \\
sec & 451.08 & 747.23 & 0.60 & 0.546 & -1017.85 & 1920.01 \\
taxex & 1855.07 & 611.96 & 3.03 & 0.003 & 652.06 & 3058.08 \\
natures & -744.17 & 493.74 & -1.51 & 0.133 & -1714.79 & 226.45 \\
gnp & -824.31 & 390.84 & -2.11 & 0.036 & -1592.64 & -55.99 \\
legal & 1357.42 & 492.74 & 2.75 & 0.006 & 388.78 & 2326.07 \\
geoloc & -335.81 & 450.08 & -0.75 & 0.456 & -1220.59 & 548.97 \\
indpol & 1334.85 & 544.29 & 2.45 & 0.015 & 264.86 & 2404.85 \\
cons & 10656.87 & 569.29 & 18.72 & 0.000 & 9537.74 & 11776.01 \\
\hline
\end{tabular}

Table A4. Econometric results for the efficiency for the Main model.

\begin{tabular}{ccccccc}
\hline fdi & Coef. & Std. Err. & $z$ & $P>|z|$ & \multicolumn{2}{c}{$[95 \%$ Conf. Interval] } \\
\hline ifra & -1793.77 & 612.90 & -2.93 & 0.004 & -2998.59 & -588.95 \\
taxex & 1669.08 & 598.47 & 2.79 & 0.006 & 492.62 & 2845.54 \\
natures & -780.00 & 482.41 & -1.62 & 0.107 & -1728.32 & 168.31 \\
gnp & -725.08 & 384.22 & -1.89 & 0.060 & -1480.38 & 30.22 \\
legal & 1500.83 & 477.93 & 3.14 & 0.002 & 561.33 & 2440.33 \\
indpol & 1008.44 & 509.36 & 1.98 & 0.048 & 7.14 & 2009.73 \\
_cons & 10525.29 & 434.10 & 24.25 & 0.000 & 9671.94 & 11378.64 \\
\hline
\end{tabular}


Table A5. Econometric results to prove the probit model.

\begin{tabular}{cccccc}
\hline impde & Coef. & Std. Err. & $z$ & $P>|z|$ & {$[95 \%$ Conf. Interval] } \\
\hline ifra & 1136.8890 &. &. &. &. \\
qualab & 799.6224 &. &. &. &. \\
wage & 964.4003 &. &. &. &. \\
sec & (omitted) &. &. &. &. \\
taxex & (omitted) &. &. &. &. \\
natures & 1144.2140 &. &. &. &. \\
gnp & 825.5351 &. &. &. &. \\
legal & 969.5341 &. &. &. &. \\
geoloc & 1264.3780 &. &. &. &. \\
indpol & 746.6990 &. &. &. &. \\
cons & -4516.5250 &. &. &. &. \\
\hline
\end{tabular}

Table A6. Econometric results for the efficiency for the probit model.

\begin{tabular}{ccccccr}
\hline impde & Coef. & Std. Err. & $z$ & $P>|z|$ & \multicolumn{2}{c}{$[95 \%$ Conf. Interval] } \\
\hline ifra & 2.2847 & 0.2833 & 8.07 & 0.000 & 1.7295 & 2.8399 \\
qualab & 1.3868 & 0.3034 & 4.57 & 0.000 & 0.7921 & 1.9815 \\
natures & 1.2455 & 0.3496 & 3.56 & 0.000 & 0.5602 & 1.9307 \\
gnp & 1.0956 & 0.2668 & 4.11 & 0.000 & 0.5726 & 1.6186 \\
indpo1 & 1.7159 & 0.2759 & 6.22 & 0.000 & 1.1751 & 2.2567 \\
_cons & -3.8730 & 0.5418 & -7.15 & 0.000 & -4.9349 & -2.8112 \\
\hline
\end{tabular}

